\title{
FACTORS INFLUENCING CONSUMER BEHAVIOR TO Purchase Sustainable Cosmetic Products in a GERMAN CONTEXT
}

\author{
Stefanie BRÜCKEL, Sandra SCHNEIDER \\ Kaposvár University, Doctoral School in Management and Organizational Sciences, \\ H-7400 Kaposvár, Guba Sándor u. 40.
}

\begin{abstract}
In today's markets, corporate social responsibility is a new consumer expectation. Organizations across all industries are trying to meet these expectations by building a positive reputation and sending a signal to their stakeholders. However, consumers' environmental behavior is not always the result of their positive attitudes towards environmental issues. Potentially, their environmentally friendly attitudes are contradicted by their actual behavior. This means that people, who have positive attitudes about sustainable products and state that they would purchase them, may not actually buy them after all. In addition, consumers often do not wish to spend more money on buying sustainably, even if they have higher expectations towards sustainable products or companies. Further research is therefore needed to explain the gap between consumer awareness and actual purchasing behavior. In several contexts, environmentally friendly consumption, called sustainable consumption, has been explained by the theory of planned behavior (TPB), such as when buying food or apparel. Sustainable consumption often results from planned decisions rather than hedonic reasons.
\end{abstract}

Keywords: environmental purchase decisions, sustainable consumption, sustainable cosmetics, theory of planned behavior

\section{INTRODUCTION}

Very few topics have experienced a newfound and revived interest in the recent decade alike the topic of sustainability (Gonzalez, 2018; McDonald et al., 2012; Miniero et al., 2014; White et al., 2019). Already in 1987, the Brundtland Report formulated by the United Nations constituted that the continuance of human civilization required of each generation to engage in business practices that safeguarded not only the current generation's livelihood but also the one of generations to come (Brundtland, 1987). Subsequently, the view on environmental and sustainability concerns as being instrumental and relevant not only for mankind but especially the economic sector, has grown. Increasingly experiencing the effects of climate change, with water and clean air resources drastically diminishing, and pictures of entire slums being built and one-use plastic have led to the topic of sustainability moving to the forefront of our everyday lives as well as business practices. While in the latter the term "triple-bottom" line was coined as a strategic mean to value environmental goals equivalently to social and economic ones (European Commission, 2001), environmental awareness has been of interest to the individual consumer for a few years and cumulated recently into activism 
throughout all demographics and nearly all levels of society with individuals like Greta Thunberg being defined as the figurehead of these movements.

Indisputably, individual and social activism is needed in order to tackle the multitude of problems society is already and will be facing furthermore in the future in terms of providing amongst others habitable land, potable water, clean air to breathe. But of corresponding value will be the organized activism of organizations, corporations, economies and governments as the latter define and subsidize the framework for individuals and companies alike to pursue a more sustainable lifestyle, while organizations and companies, which focus on their triple-bottom line and make this an inherent element of their mission, proliferate opportunities for individuals to bring their natural interest of caring for this planet into the workplace as well.

Since the topic of sustainability has become of increasing interest in the last decade, a number of industries have invested into adapting their operations accordingly (e.g. coffee, automobile, consumer goods) (Chang and Watchravesringkan, 2018). Recently, another industry has started to incorporate more strongly a more sustainable mindset into its production by sourcing and utilizing more organic ingredients (Ashraf et al., 2019; Demirtas, 2018; Emekci, 2019; Tarkiainen, 2005). This industry is the cosmetics industry, which will be the focus of the following analysis. From the outset, it must be mentioned that cosmetics in the understanding of this paper refers to not only makeup and toiletries but also skin- and haircare as well as perfumes and hygiene articles. It is important to make this distinction as 'cosmetics' might at first only be associated with products naturally more of interest to women. However, given the five categories mentioned above, make-up only amounts to $19 \%$ of the cosmetic market, whereby skin- and haircare are in fact the largest categories with $39 \%$ and $21 \%$ respectively (L'Oréal, 2015). In addition to a market that is split into only a small number of main product categories which appeal to a large segment of the society, the fact that the cosmetics market is largely controlled by five multinational enterprises making up 50\% of the market share (Varquez-Burguete et al., 2017) facilitated the decision to place the study into this context.

The main goal of this research is to analyze which factors influence German consumers in their purchasing behavior when buying sustainable cosmetic products. With the next section explaining the utilized model of Theory of Planned Behavior, further sections provide information regarding the structure, distribution and implementation of an online survey that was run for two months in the summer of 2019 and amounted to 268 responses in total, out of which in the end $n=245$ were used in the analysis. Eventually, a discussion of the findings will be provided and a conclusion drawn before the paper closes with a short reflection on the limitations this research encountered.

\section{CONCEPTUAL FRAMEWORK}

The Theory of Planned Behavior model (TPB) focuses on the attitudes and behavior that have the strongest impact on an individual's purchasing choices (Ajzen, 1985, 1991). The model hereby demonstrates the relation between five constructs - attitude, subjective norms, purchase intention, perceived behavioral control and behavior (Ajzen, 2008) - and how each of them influences the individual's purchase intention. 
Through the application of the TPB, researchers have been able to provide stable evidence of consumption patterns and purchasing intensions (Conner et al., 2000; Martin et al., 2010; Norman et al., 1999; Zemore and Ajzen, 2014). Aside from being a well-received and -researched model, another strength of the TPB is the possibility to extend the model for further constructs, which might be of particular interest with regards to the research field. In the underlying research, two additional constructs were added, namely trustworthiness and perceived consumer effectiveness. While each of the constructs will be analyzed individually in the following, it must be said that the reason to append the original model was twofold. First, since cosmetic products can directly impact on a person's health if hazardous ingredients are used, trusting a product or a company is the basis for the consumer to even consider engaging in purchasing behavior (Pudaruth et al., 2015). Secondly, individuals often state that they feel their own individual contribution to live a more sustainable, eco-friendly life, but it does not have a measurable effect (Newsom et al., 2005; Paladino, 2005; Peattie, 2001). Thus, in the context of cosmetic products it is especially interesting to see whether the consumption of products in daily use and towards the improvement of external characteristics of the consumer is significantly shaped by the intrinsic motivation of an individual to primarily purchase eco-friendlier options for the benefit of sustainability.

\section{Trustworthiness}

As mentioned before, the construct of trustworthiness was added to the original TPB model because it is believed that consumers engaged in purchasing intentions need to be willing to rely on the information provided by the seller of being true (Jarvenpaa et al., 2000). While the concept of trust has been researched in a multitude of different research fields, in the context of consumer behavior it has been found that trust is a factor any consumer engages in on different levels during the purchasing experience (Sekhon et al., 2014). The psychological process involved herein accumulates in customers believing and trusting the integrity of a cosmetic product producer and thus considering to purchase one of their products (Berry and Parasuraman, 1991). In this way, trust becomes an instrumental and integral part of a consumer's attitude towards a potential purchase.

H1: The greater the trustworthiness (TW) of sustainable cosmetics is, the greater the purchase intention (PI) for sustainable cosmetics is.

\section{Subjective norms}

When speaking of subjective norms, both innate and indiscernible pressures presented to the consumer through the upbringing, socialization and environment as well as more offensive, external expressions of peer pressure are referred to. In this understanding, subjective norms describe the social environment each consumer finds themselves in and that shapes the attitudes towards a certain product as much as it is a determent of the purchasing intention (Du et al., 2017; Teng and Lu, 2016; Hansen et al., 2018). Newholm and Shaw (2002) found that with the more globalized, digitalized and also more expressive world of today social norms were also constructed and influenced through various channels of the media, pop culture and education. In aggregation, social norms are the pressures each individual perceives as 
motivating influences to comply in the purchasing behavior with important persons of reference or in order to confirm with perceived expectations.

H2: The greater the influence of the subjective norm (SN) on the purchase of sustainable cosmetics is, the greater the purchase intention (PI) for sustainable cosmetics is.

\section{Attitudes}

In the original TPB model, Ajzen 1991 stated that positive attitudes towards a product lead to a more favourable evaluation of the product by the consumer. Attitudes develop from an individual's belief about what performing a certain act (Fishbein and Ajzen, 1975) means, and similarly to subjective norms, are formed by the social environment, health concerns, product quality, the environmental knowledge and consciousness of the individual consumer (Demirtas, 2019) and the experiences any consumer has and makes throughout life. Attitudes can be both positive and negative but it is presumed that a more positive attitude towards a product leads to a higher likelihood of the positive consequences of an engagement in purchasing intention.

H3: The more positive the attitude (AT) towards sustainable cosmetics is, the greater the purchase intention (PI) for sustainable cosmetics is.

\section{Perceived behavioral control}

While an individual's impact on any purchasing decision might be limited, in the context of sustainable consumption, the perceived behavioral control gains additional weight as despite their environmental intentions, sustainably minded consumers might end up not purchasing the more sustainable product (Carrington et al., 2010) for either of the following two reasons. Either, because the perception is that purchasing a sustainable product brings no added value if the majority of customers remains purchasing traditionally less eco-friendly products or because the products are too expensive or not readily available enough for the consumer to be willing to go through the additional effort. Thus, the contemplation of individual perceived behavior control must occur before the intention of engaging in a purchase intent even begins, as only this way a positive outcome of the consideration leads to purchase intent and behavior (Chang and W atchravesringkan, 2018). H4: The greater the perceived behavioral control (PBC) in relation to the purchase of sustainable cosmetics is, the greater the purchase intention (PI) for sustainable cosmetics is.

Given the second dimension of PBC mentioned before, it is also described as the perceived difficulty or ease of an individual being able to carry out behavior and being able to overcome any volatile external factors that might interfere with a person's actual behavior towards purchasing a sustainable cosmetic product (Ajzen, 1991; Taylor and Todd, 1995).

H5: The greater the perceived behavioral control (PBC) in relation to the purchase of sustainable cosmetics is, the more positive the actual behavior (BE) to buy sustainable cosmetics is.

\section{Perceived consumer effectiveness}

Along the same lines of PBC, the belief that the individual's actions might have a positive impact on solving an environmental issue as a result of the individual efforts (Gonzalez et al., 2015) plays a large role in the constitution of an individual's belief system. Similarly, to TW, PCE is a mainly psychological variable that attempts to explain certain attitudes 
found and yet has been to be one of the best predictors for ecologically conscious behavior (Akehurst et al., 2012; Stranghan and Roberts, 1999; Moisander, 2007).

H6: The greater the perceived consumer effectiveness (PCE) through the use of environmentally friendly products is, the more positive the attitude (AT) towards sustainable cosmetics is.

\section{Purchase Intention}

Eventually, the main indicator in the TPB is the intent, as the best indicator and determining factor for a purchasing behavior (Singh and Verma, 2017). The intent is viewed as the most important and best predictor because it can also be seen as a direct antecedent of behaviour (Fishbein and Ajzen, 1975). Yet, good intentions alone do not always translate into behavior in cases where other factors become overwhelming (e.g. price or previous experiences) (Bray et al., 2011) and overshadow the intent. According to TPB, the execution of behavior is the joint function of intentions and perceived behavioral control (Tarkianinen and Sundqvist, 2005)

H7: The more positive the purchase intention (PI) for sustainable cosmetics is, the more positive the actual behavior (BE) for sustainable cosmetics is.

\section{Survey and items}

The survey used in this research consisted of a total number of 29 questions with at least two questions (items) being allocated to each of the previously described constructs. The items were confirmed through the research of Ashraf et al. (2019), Demirtas (2019) and Emekci (2019). The survey closed with four questions regarding the demographics of the respondents and a comment box for open-ended feedback.

\section{MATERIALS AND METHODS}

The constructs of the developed explanatory model for the acceptance of sustainable cosmetics are latent variables that were measured based on established scales. The scales were adapted to the present context and translated into German. A 5-point Likert scale was used continuously to measure the items. While the construct Subjective norms is a formative latent variable, the other variables were operationalized reflectively. The data collection was conducted as an online survey from July $30^{\text {th }}$ to September $26^{\text {th }}$ 2019. In total, there were 268 returns. All data records with more than $20 \%$ missing values were removed (22 cases and 1 question). The remaining data set still contains $0.15 \%$ missing values, which is however only a small percentage. Nevertheless, since the estimates of structural equation models require complete data sets (Weiber and Mühlhaus, 2013), the missing values were supplemented by mean value replacement. One disadvantage of using the mean value is a possible distortion of the quantiles or variances (Göthlich, 2009). However, due to the very low proportion of missing values, the risk is assessed as very low and this procedure is applied.

Thus, a total of $n=245$ data records are available. The sample consists of $66.12 \%$ female and $33.88 \%$ male respondents. Comparing the ratio to the actual population distribution in Germany (50.65\% and 49.35\%, respectively), women are overrepresented in the sample. Almost $60 \%$ of the participants were between the age of 26 and 45 . Only about $16 \%$ are younger than 25 years. Slightly more than $24 \%$ of 
the respondents were 46 years and older. The interviewees over 65 years are relatively underrepresented. Almost 40\% have a partner and children. Another 35.5\% live with a partner but without children. Nearly $25 \%$ are single or widowed and are focusing entirely on themselves in their decision-making process.

For the first assessment of the data set, the position and scattering measures were checked. It can be seen that the respondents used the entire scale (1-5) for almost all indicators. Six indicators have a median of 5 and a standard deviation of less than 0.84 . This suggests that most of the respondents have the same subjective perception for these six indicators.

\section{RESULTS AND DISCUSSION}

At first, the reliability of the items was examined (Table 1). The factor loadings of 4 items are less than 0.7 and were removed from the measuring model. The remaining factor loadings of items were above 0.704 and significant at $p<0.001$.

Table 1.

Reliability of reflective indicators

\begin{tabular}{|c|c|c|c|c|c|}
\hline Construct & Indicator & $\begin{array}{c}\text { Presumed } \\
\text { Effect }\end{array}$ & Loading & t-value & $\begin{array}{c}\text { One-sided } \\
\text { p-value }\end{array}$ \\
\hline \multirow{5}{*}{ Attitude } & AT_001 & + & 0.704 & 16.343 & 0.000 \\
\hline & AT_002 & + & 0.820 & 25.705 & 0.000 \\
\hline & AT_003 & + & 0.836 & 28.305 & 0.000 \\
\hline & AT_004 & + & 0.856 & 37.933 & 0.000 \\
\hline & AT_005 & + & 0.779 & 20.079 & 0.000 \\
\hline \multirow{3}{*}{ Behavior } & BE_001 & + & 0.884 & 60.185 & 0.000 \\
\hline & BE_002 & + & 0.823 & 28.382 & 0.000 \\
\hline & BE_003 & + & 0.613 & 9.197 & 0.000 \\
\hline \multirow{5}{*}{$\begin{array}{l}\text { Perceived } \\
\text { Behavioral Control }\end{array}$} & PBC_001 & + & 0.832 & 34.293 & 0.000 \\
\hline & PBC_002 & - & -0.197 & 2.024 & 0.043 \\
\hline & PBC_003 & + & 0.440 & 6.040 & 0.000 \\
\hline & PBC_004 & + & 0.834 & 32.263 & 0.000 \\
\hline & PBC_005 & + & 0.875 & 49.021 & 0.000 \\
\hline \multirow{2}{*}{$\begin{array}{l}\text { Perceived Consumer } \\
\text { Effectiveness }\end{array}$} & PCE_001 & + & 0.899 & 40.838 & 0.000 \\
\hline & PCE_002 & + & 0.878 & 27.011 & 0.000 \\
\hline \multirow{2}{*}{ Purchase Intention } & PI_001 & + & 0.913 & 77.433 & 0.000 \\
\hline & PI_002 & + & 0.895 & 43.550 & 0.000 \\
\hline \multirow{4}{*}{ Trustworthiness } & TW_001 & + & 0.484 & 2.987 & 0.003 \\
\hline & TW_002 & + & 0.749 & 15.166 & 0.000 \\
\hline & TW_003 & + & 0.788 & 19.156 & 0.000 \\
\hline & TW_004 & + & 0.828 & 21.206 & 0.000 \\
\hline
\end{tabular}


In a next step, the internal consistency reliability and the convergent validity of the reflective multi-item scales were evaluated by calculating Cronbach's alpha, average variance extracted (AVE) and internal consistence value (IC).

All Cronbach's alphas exceeded the required value of 0.7 (Nunnally and Bernstein, 1994) and every AVE as well as IC value clearly surpassed the required threshold value of 0.5 and 0.6 respectively (Bagozzi and $Y i$, 1988). Discriminant validity based on Fornell-Larcker was fulfilled (Table 2). Furthermore, evaluating of the cross loadings show that no indicator loading is higher compared to the other constructs than its own construct (Homburg and Giering, 1996).

Table 2

\section{Squared construct correlations and AVE values}

\begin{tabular}{|c|c|c|c|c|c|c|}
\hline & AVE & 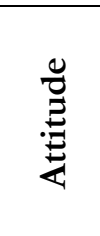 & • & 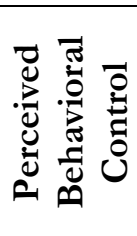 & 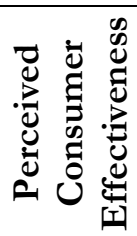 & 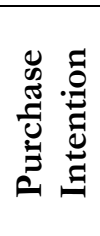 \\
\hline Attitude & 0.641 & & & & & \\
\hline Behavior & 0.809 & 0.566 & & & & \\
\hline $\begin{array}{l}\text { Perceived } \\
\text { Behavioral } \\
\text { Control }\end{array}$ & 0.747 & 0.683 & 0.742 & & & \\
\hline $\begin{array}{l}\text { Perceived } \\
\text { Consumer } \\
\text { Effectiveness }\end{array}$ & 0.789 & 0.433 & 0.530 & 0.462 & & \\
\hline $\begin{array}{l}\text { Purchase } \\
\text { Intention }\end{array}$ & 0.817 & 0.529 & 0.660 & 0.669 & 0.583 & \\
\hline Trustworthiness & 0.665 & 0.556 & 0.452 & 0.536 & 0.351 & 0.373 \\
\hline
\end{tabular}

Turning to the formative measured construct, all item weights of the formative measurement models are positive and differ significantly from zero. One item does not show a positive weight as assumed but in fact a negative one (PBC_002). Since the $\mathrm{t}$-value is also not significant, this item was removed from the model. The $\mathrm{t}$-values of the other two items are significant or even highly significant. After elimination, the remaining VIF values are all less than 2. There are no problems detectable due to multicollinearities (Hair et al., 2017).

On the basis of a valid measuring model, a structural model was analyzed by examining the explanatory power of the model as well as the predictive power of the respective independent variables. To test the theoretical models, PLS path modelling using the software application SmartPLS 3 was applied (Ringle et al., 2015). As no multicollinearity issues were perceived and inner VIFs showed values less than five (Hair et al., 2017), the explanatory power by examining $\mathrm{R}^{2}$ of the main dependent variables was assessed first. The endogenous variables are determined by the coefficient of determination $\mathrm{R}^{2}$ adj. Purchase 
Intention shows an $\mathrm{R}_{\text {adj }}^{2}$ of $45 \%$ and Behavior $60 \%$. Both have a moderate explanatory power. Attitude shows an $\mathrm{R}_{\text {adj }}$ of only $18 \%$ and falls below the limit of weak explanatory power. In the next step, the predictive power of the independent variables was analyzed by examining the standardized estimates of path coefficients and their significance (Figure 1).

\section{Figure 1.}

\section{Path analysis results}

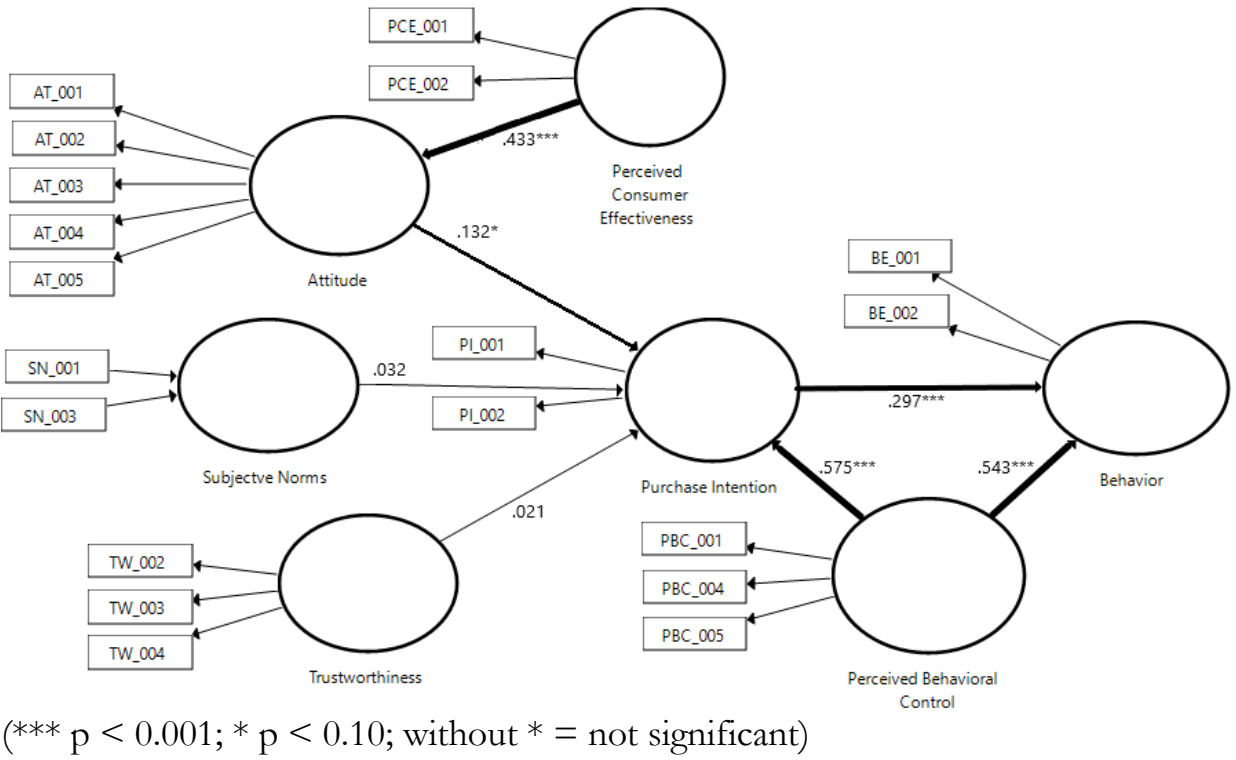

In the hypothesized model, five out of seven path coefficients are significant. The results confirm most of the constructs of the original TPB model. Purchase intention $\left(\beta=0.297, \mathrm{p} \leq 0.001, \mathrm{f}^{2}=0.12\right)$ has a positive influence on behaviour. Also perceived behavioral control shows nearly the same impact on purchase intention $(\beta=0.575, \mathrm{p} \leq 0.001$, $\left.\mathrm{f}^{2}=0.30\right)$ as the behaviour $\left(\beta=0.543, \mathrm{p} \leq 0.001, \mathrm{f}^{2}=0.41\right)$. The subjective norms show an insignificant and very low impact $\left(\beta=0.03, \mathrm{p} \geq 0.1, \mathrm{f}^{2}=0.001\right)$. It seems that the subjective norms, other than in the TPB model, have no effect on the purchase intention. The last TPB-construct is attitude. This shows a significant but limited influence on purchase intention $\left(\beta=0.132, \mathrm{p} \leq 0.1, \mathrm{f}^{2}=0.01\right)$. The perceived consumer effectiveness shows a significant impact on attitudes $\left(\beta=0.43, \mathrm{p} \leq 0.001, \mathrm{f}^{2}=0.23\right)$. The additional construct trustworthiness has no impact on purchase intention $\left(\beta=0.02, \mathrm{p} \geq 0.1, \mathrm{f}^{2}=0.001\right)$. The blind folding shows that the prediction relevance of the model is given, as all values are larger than 0 (Weiber and Mühlhaus, 2013).

\section{CONCLUSION}

Based on the TPB model, the perceived behavioral control shows an impact on the purchase intention and buying behavior of sustainable cosmetics. Therefore, it 
should be important to give the customers the opportunity to inform themselves and decide to buy without external control. It makes sense to include this freedom of choice in marketing communication.

Both an improved perceived company image as well as social pressure were found to be irrelevant for the consumer in this analysis. Similarly, trustworthiness showed no influence on the intention to purchase a sustainable cosmetic product.

The median of attitudes of 5 shows that the interviewee's convictions towards sustainable cosmetics is generally very similar. However, the variance explained by the model is only low indicating that there must be other influencing variables. These should be determined in further research with a focus on explaining the attitude and intention to buy. Furthermore, this research paper did not look for moderating variables, which future research could include.

The perceived consumer effectiveness has a high influence on the attitude. The respondents have the feeling that with sustainable cosmetics and other environmentally friendly products they are protecting the environment and making a positive contribution. The survey was conducted exclusively in Germany. However, sustainable cosmetics are also offered in other countries. In order to obtain an international picture of the influence factors and to eliminate social and cultural biases, the same research should be carried out in further countries as well.

\section{REFERENCES}

Ajzen, I. (1985): From intentions to actions: a theory of planned behavior. In: Kuhl, J., Beckman, J. (eds.): Action Control: From Cognition to Behavior, Berlin Heidelberg: Springer-Verlag, 11-39. p. ISBN: 978-3-642-69748-7

Ajzen, I. (1991): The theory of planned behavior. In: Organizational Behavior and Human Decision Processes, 50. 2. 179-211. p. doi: 10.1016/07495978(91)90020-T

Ajzen, I. (2008): Consumer attitudes and behavior. In Haugtvedt, C.P., Herr, P.M., Cardes, F.R. (Eds): Handbook of Consumer Psychology, New York, NY, Lawrence Earlbaum Associates, 525-548. p. ISBN-13: 9780805856033

Akehurst, G., Afonso, C., Gonçalves, H.M. (2012): Re-examining green purchase behaviour and the green consumer profile: new evidences. In: Management Decision. 50. 5. 972-988. p. doi: 10.1108/00251741211227726

Ashraf, M.A., Joarder, M.H.R., Ratan, S.R.A. (2019): Consumers' anti-consumption behavior toward organic food purchase: an analysis using SEM. In: British Food Journal. 121. 1. 104-122. p. doi: 10.1108/BFJ-02-2018-0072

Bagozzi, R.P., Yi, Y. (1988): On the Evaluation of Structural Equation Models. In: Journal of the Academy of Marketing Science. 16. 1. 74-94. p. doi: $10.1007 / \mathrm{BF} 02723327$

Berry, L.L., Parasuraman, A. (1991), Marketing Services: Competing through Quality. New York: The Free Press, 212. p. ISBN-13: 9780029030790

Bray, J., Johns, N., Kilburn, D. (2011): An exploratory study into the factors impeding ethical consumption. In: Journal of Business Ethics. 98. 4. 597-618. p. doi: 10.1007/s10551-010-0640-9 
Brundtland, G. (1987): Our Common Future: The World Commission on Environment and Development, Oxford University Press, Oxford. 416. p. ISBN-13: 978-0192820808

Carrington, M.J., Neville, B.A., Whitwell, G.J. (2010): Why ethical consumers don't walk their talk: towards a framework for understanding the gap between the ethical purchase intentions and actual buying behavior of ethically minded consumers. In: Journal of Business Ethics. 97. 1. 139-159. p. doi: 10.1007/s10551-010-0501-6

Chang, H.J., Watchravesringkan, K.T. (2018): Who are sustainably minded apparel shoppers? An investigation to the influencing factors of sustainable apparel consumption. In: International Journal of Retail and Distribution Management, 46. 2. 148-162. p. doi: 10.1108/IJRDM-10-2016-0176

Conner, M., Norman, P., Bell, R. (2000): The theory of planned behavior and healthy eating. In: Health Psychology, 21. 2. 194-201. p. doi: 10.1037/02786133.21.2.194

Demirtas, B. (2019): Assessment of the impacts of the consumers' awareness of organic food on consumption behavior. In: Food Science and Technology. 39. 4. 881-888. p. doi: 10.1590/fst.10518

Du, S., Bartels, J., Reinders, M., Sen, S. (2017): Organic consumption behavior: A social identification perspective. In: Food Quality and Preference. 62. 190-198. p. doi: 10.1016/j.foodqual.2017.07.009

Emekci, S. (2019): Green consumption behaviours of consumers within the scope of TPB. In Journal of Consumer Marketing. 36. 3. 410-417. p. doi: 10.1108/jcm05-2018-2694

European Commission (2001): Green Paper. Promoting a European Framework for Corporate Social Responsibility. [online] <URL:

https://ec.europa.eu/commission/presscorner/api/files/document/print/en /doc_01_9/DOC_01_9_EN.pdf>

Fishbein, M., Ajzen, I. (1975): Belief, Attitude, Intention, and Behavior: An Introduction to Theory and Research. Reading, MA: Addison-Wesley, 578. p. ISBN-13: 978-0-201-02089-2

Gonzalez, A. (2018): Making sustainability a lifestyle rather than a philosophy. In: International Trade Forum. 3. 3.p.

González, E.M., Felix, R., Carrete, L., Centeno, E., Castaño, R. (2015): Green shades: a segmentation approach based on ecological consumer behavior in an emerging economy. In: Journal of Marketing Theory and Practice. 23. 3. 287-302. p. doi: 10.1080/10696679.2015.1032395

Göthlich, S.E. (2009) Zum Umgang mit fehlenden Daten in großzahligen empirischen Erhebungen. In: Albers, S., Klapper, D., Konradt, U., Walter, A., Wolf, J. (eds) Methodik der empirischen Forschung. Wiesbaden: Gabler Verlag, 119-135. p. doi: 10.1007/978-3-322-96406-9_9

Hair, J.F., Hult, G.T.M., Ringle, C.M., Sarstedt, M. (2017): A Primer on Partial Least Squares Structural Equation Modeling (PLS-SEM). 2nd ed., Los Angeles: Sage Publication, 384. p. ISBN-13: 978-1483377445 
Hansen, T., Sørensen, M.I., Eriksen, M.L.R. (2018): How the interplay between consumer motivations and values influences organic food identity and behavior? In: Food Policy. 74. 39-52. p. doi: 10.1016/j.foodpol.2017.11.003

Homburg, C., Giering, A. (1996): (DE) Konzeptionalisierung und Operationalisierung komplexer Konstrukte - Ein Leitfaden für die Marketingforschung. In: Marketing: ZFP; Journal of Research and Management, 18. 1. 3-24. p.

Jarvenpaa, S.L., Tractinsky, N., Vitale, M. (2000): Consumer trust in an internet store. In: Information Technology and Management. 1. 45-71. p. doi: 10.1023/a:1019104520776

L'Oréal (2015). Annual Report 2014. [online]<URL: https://www.lorealfinance.com/system/files/2019-10/LOREAL_Annual_Report_2014_ENG.pdf>

Martin, R.J., Usdan, S., Nelson, S., Umstattd, M.R., LaPlante, D., Perko, M., Shaffer, H. (2010): Using the theory of planned behavior to predict gambling behaviour. In: Psychology of Addictive Behaviors. 24. 1. 89-97. p. doi: 10.1037/a0018452

McDonald, S., Oates, C.J., Alevizou, P.J., Young, C.W., Hwang, K. (2012): Individual strategies for sustainable consumption. In: Journal of Marketing Management. 28. 3-4. 445-468. p. doi: 10.1080/0267257x.2012.658839

Miniero, G., Codini, A., Bonera, M., Corvi, E., Bertoli, G. (2014): Being green: from attitude to actual consumption. In: International Journal of Consumer Studies. 38. 5. 521-528. p. doi: $10.1111 /$ ijcs. 12128

Moisander, J. (2007): Motivational complecity of green consumerism. In: International Journal of Consumer Studies. 31. 4. 404-409. p. doi: 10.1111/j.1470-6431.2007.00586.x

Newholm, T., Shaw, D. (2002): Studying the ethical consumer: a review of research. In: Journal of Consumer Behaviour. 6. 5. 253-270. p. doi: 10.1002/cb.225

Newsom, J.T., Mcfarland, B.H., Kaplan, M.S., Huguet, N., Zani, B. (2005): The health consciousness myth: Implications of the near independence of major health behaviors in the north American population. In: Social Science \& Medicine. 60. 2. 433-437. p. doi: 10.1016/j.socscimed.2004.05.015

Norman, P., Conner, M., Bell, R. (1999): The theory of planned behavior and smoking cessation. In: Health Psychology: Official Journal of the Division of Health Psychology, American Psychological Association. 18. 1. 89-94. p. doi: 10.1037/0278-6133.18.1.89

Nunnally, J.C., Bernstein, I.H. (1994): Psychometric Theory. $3^{\text {rd }}$ ed., New York: McGraw-Hill Education. 736. p. ISBN-13: 978-0070478497

Paladino, A. (2005). Understanding the green consumerism: An empirical analysis. Journal of Customer Behaviour, 4. 1. 69-102. p. doi: 10.1362/1475392053750306

Peattie, K. (2001): Golden goose or wild goose? The hunt for the green consumer. In: Business Strategy and the Environment. 10. 4. 187-199. p. doi: 10.1002/bse. 292

Pudaruth, S., Juwaheer, T.D., Seewoo, Y.D. (2015): Gender-based differences in understanding the purchasing patterns of eco-friendly cosmetics and beauty care products in Mauritius: a study of female customers. In: Social Responsibility Journal. 11. 1. 179-198. p. doi: 10.1108/srj-04-2013-0049 
Ringle, C.M., Wende, S., Becker, J.-M. (2015). SmartPLS 3. Boenningstedt: SmartPLS GmbH. [online] <URL: http://www.smartpls.com>

Sekhon, H., Ennew, C., Kharouf, H., Delvin, J. (2014): Trustworthiness and trust: influences and implications. In: Journal of Marketing Management. 30. 3-4. 409430. p. doi: 10.1080/0267257x.2013.842609

Singh, A., Verma, P. (2017): Factors influencing Indian consumers' actual buying behaviour towards organic food products. In: Journal of Cleaner Production. 167. 473-483. p. doi: 10.1016/j.jclepro.2017.08.106

Straughan, R., Roberts, J. (1999): Environmental segmentation alternatives: a look at green consumer behaviour in the new millennium. In: Journal of Consumer Marketing. 16. 6. 558-575. p. doi: 10.1108/07363769910297506

Tarkiainen, A., Sundqvist, S. (2005): Subjective norms, attitudes and intentions of Finnish consumers in buying organic food. In: British Food Journal. 107. 11. 808-822. p. doi: 10.1108/00070700510629760

Taylor, S., Todd, P.A. (1995): Understanding Information Technology Usage: A Test of Competing Models. In: Information Systems Research. 6. 2. 144-176. p. doi: 10.1287/isre.6.2.144

Teng, C.-C., Lu, C.-H. (2016): Organic food consumption in Taiwan: Motives. involvement. and purchase intention under the moderating role of uncertainty. In: Appetite. 105. 95-105. p. doi: 10.1016/j. appet.2016.05.006

Vázquez-Burguete, J.L., Sahelices-Pinto, C., Lanero-Carrizo, A. (2017): Corporate social responsibility and consumer behavior in the cosmetics sector: a study in the Spanish context. In: International Review on Public Nonprofit Market. 14. 3. 375-390. p. doi: 10.1007/s12208-017-0178-y

Weiber, R., Mühlhaus, D. (2013): (DE) Strukturgleichungsmodellierung - Eine anwendungs-orientierte Einführung in die Kausalanalyse mit Hilfe von AMOS, SmartPLS und SPSS. $2^{\text {nd }}$ ed. Berlin: Springer-Lehrbuch. doi: 10.1007/978-3642-35012-2

White, K., Habib, R., Hardisty, D.J., (2019): How to SHIFT Consumer Behaviors to be More Sustainable: A Literature Review and Guiding Framework. In: Journal of Marketing. 83. 3. 22-49. p. doi: 10.1177/0022242919825649

Zemore, S.E., Ajzen, I (2014): Predicting substance abuse treatment completion using a new scale based on the theory of planned behavior. In: Journal of Substance Abuse Treatment. 46. 2. 174-182. p. doi: 10.1016/j.jsat.2013.06.011

Corresponding author:

\section{Stefanie BRÜCKEL}

Kaposvár University,

Doctoral School in Management and Organizational Sciences,

H-7400 Kaposvár, Guba Sándor u. 40.

stefanie.bruckel@ke.hu 